\title{
Accounting
}

\section{Analyzing the cash conversion cycle relationship with the financial performance of chemical firms: Evidence} from Amman Stock Exchange

\author{
Mohammed Ibrahim Sultan Obeidat ${ }^{a^{*}}$, Tareq Mohammad Almomani ${ }^{a}$ and Mohammad Abdullah \\ Almomania
}

aAccounting Department, Jadara University, Irbid, Jordan

\section{H R O N I C L E}

\section{Article history:}

Received: November 30, 2020

Received in revised format:

April 32021

Accepted: April 4, 2021

Available online:

April 6, 2021

Keywords:

Cash Conversion Cycle

Financial Performance

Profitability

Return on Equity

Earnings per Share

\section{A B S T R A C T}

The main purpose of the study is to investigate whether the cash conversion cycle has an impact on the financial performance of listed chemical firms in Amman Stock Exchange. To achieve the objectives of the study, data covering the period 2010-2019 of 5 among a total of 6 listed chemical firms were collected and used in analysis and hypotheses testing. The excluded firm was eliminated because its information was incomplete along the study period. Return on equity and earnings per share were used as indicators for financial performance in a separate form. The study involved two hypotheses, and both hypotheses were tested under the 95 percent level of confidence. Descriptive statistics including the mean and variance, in addition to correlation, were used in data analysis. Using both of the multiple and single regression models, the study showed that the cash conversion cycle had a significant impact on the financial performance of firms. Moreover, both of the controls were found significantly affecting the financial performance.

\section{Introduction}

Cash is considered as the most important asset of business organizations, whatever the type, nature, form, or size of the firm. When a firm has sufficient cash, it can maintain the continuity of its operations, since cash assets are used in purchasing materials and other needed assets and can be used for paying labor and other expenses. A shortage in cash creates several difficulties for a business organization, and excessive amounts of cash leads to a decline in firm profitability. Therefore, cash management is considered an important and critical issue (Abioro, 2013). It is true that most transactions can be accomplished on account, but the credit period is limited, and the time to pay these on account purchases or expenses will be due, and using cash in payment is necessary. The way the cash asset is managed, may lead to success or failure. Peavler (2009), mentioned that cash is the common reason standing behind business failure. As a result, business organizations are required to keep enough cash, without holding too much extra amounts, because extra amounts of cash can be invested to generate return. A firm may be profitable, but it should be careful of its liquidity. Many firms focus on achieving profits and neglect the cash flow issue. High profits underline the accrual basis can be achieved, but the most important issue is to keep higher cash inflows than cash outflows. The existence of enough cash may lead to higher profitability, because purchase discounts can be acquired when payment of the purchase price is paid within the discount period. Cash purchase price is often less than the credit purchase price. Regarding this

* Corresponding author

E-mail address: tareqmomani065@gmail.com (M. I. S. Obeidat) 
issue, Patel (2010), demonstrated that cash flow is significant for making profits. Many firms actually failed because of cash shortage, not because of losses or low profitability. Therefore, business organizations are required to be aware of its cash flow situation. This doesn't mean that profitability is not important, but business organizations are required to take care of its cash, as well as profitability. Profitable business organizations can't continue for a long period of time, when its cash inflows are less than cash outflows (Hamad, AlMomani, \& AlMawali, 2019). Based on the above illustration of the expected results of cash management, the problem of the study can be better expressed through the following question; Does the cash conversion cycle, as a measure of cash management, affect the financial performance of listed chemical firms at Amman Stock Exchange (ASE)? The study is important, where a portion of this importance is stemmed from the importance of cash to the daily operations. A large amount of cash has a small size, so it can be mismanaged, stolen, or inefficiently used. When there is an inefficient or illegal use of cash, firms will face hard financial difficulties, and it will be unable to pay its obligations when they are due. When the difficult financial situation continues for a long time, the only remaining available option is to close, because profit achievement is necessary for a firm to survive. Cash is the most liquid asset, and the way cash is managed will affect the effectiveness and efficiency of other assets management. Among the results of cash bad management and cash shortage, is the decline in inventory and therefore stoppage of operations. Less cash means that the firm encountering financial difficulties, and it will be unable to pay employee salaries and workers' wages, and a sharp continuous decline in inventory, will thereafter lead to bankruptcy. The study is looking to determine the results of the shortage or extra inventory on the financial performance. Where a decline in cash leads to delay of obligations payment and inventory decline, freezing extra amounts of cash will reduce the profitability. Therefore, one among the objectives of the study, is to determine the results of maintaining a large extra amount of cash on the financial performance. In other words, the study is an attempt to determine the results of efficient and bad cash management on firm financial performance. Moreover, the study objects for determining the effect of cash management on firm financial performance.

The remaining of the study is organized to be as follows; section 2 shows the literature and the related prior research, and section 3 lists the hypotheses of the study. The methodology of the study is available in section 4 , while section 5 demonstrates the results and the analysis. Section 6 just shows the findings of the study.

\section{Literature Review}

Cash is a crucial asset for each business organization (Coyle, 2000). Cash can be described as a life, or called as the cycle of activities (Soaga, 2012). Cash for a firm is like blood to a human being. A business organization can't continue without enough cash availability. Enough amount of cash should be available along the time for a business organization. Cash is the liquid asset that is used as a means of exchange. In other words, cash is used for paying the prices of purchases and payment of expenses, whether all or a part of these purchases and expenses were done on cash or on account, since on account purchases and expenses will be paid within a short future period of time. Neglecting paying the financial obligations when they due, destroys the reputation of business organizations, and thereafter, these organizations will encounter hard problems in future purchases or receiving services and loans. In addition to reputation detriment, when a firm has cash difficulties, and delays the payments of its financial obligations, it will be obliged to borrow at high cost. Cash means that cash is enough available in a business. Cash is related to liquidity, where liquidity, according to Guay and Harford $(2,000)$, is defined as "the ability of a company to change its assets to cash". Therefore, an asset is classified as liquid when it can be converted to cash within a short period of time, and with no loss. Cash includes cash on hand and different accounts in banks, in addition to short-term notes receivables that mature within 90 days or less. A firm is required to maintain enough amount of cash to ensure the continuity of its operations, where the words "enough cash", refers to the issue of keeping just adequate amount of cash for paying financial obligations, and not more, especially because keeping too much extra amount of cash is not acceptable in the language of investment and business. This means that a business organization is required to keep an adequate amount of cash for the payment of financial obligations, while any surplus amounts of cash should be directed towards investment to generate a return, and thereafter, increase profitability. In other words, the efficient management of cash is based on the determination of the optimal cash to hold through the trade-off between the opportunity cost of holding a high amount of cash, and the trading cost of holding a low amount of cash. Good cash management means the optimal utilization of cash and no idle cash, nor a shortage. Njeru et al. (2015), stated that cash management is a financial discipline adopting the same principles whatever the size, age, or the type of a business. It is also defined as "the management of liquidity in order to meet the day to day commitment" (Babil, 2012). Ndirangu (2014), defined cash management as "the process which involves the collection and management of cash to ensure optimal cash balances by business entities". Njeru et al. (2015), stated that cash management objects for determining and achieving the most appropriate level and structure of cash and marketable securities to the nature and objectives of the firm. Effective and efficient cash management is important to be exercised by each business organization (Aljawarneh et al., 2020), because firms' survival and growth depend on the effectiveness and efficiency of cash management (Sloaga, 2012). Efficient cash management can be achieved through the reduction of cash cycle, because a reduction in cash cycle leads to a reduction in the cost of financing (Alsafadi et al., 2020). Cash management efficiency can be achieved through several basics including; forecasting, planning, working capital cycle, internal control, competitors' comparative model analysis, cash management enterprise, top-line strategic management. 
Efficient cash flow management requires a periodic analysis of cash to sustain efficiency and effectiveness (Al-Omari et al., 2020). Cash flow analysis is considered beneficial to sustain efficient cash management. Cash flow analysis can be done through the information involved in the financial statements, especially the statement of cash flows, statement of financial position, and income statement, where several financial ratios can be determined through the relationships among the items of the financial statements. When used, most financial ratios can show the ability of a firm to generate cash, and whether the firm will be able to pay its financial obligations when they are due. Among the financial ratios that can be used in cash analysis are; operating cash flows ratio, cash current debt coverage, price cash flow ratio, cash flow margin ratio, cash flows from operations to average total liabilities ratio, net income to operating cash flow ratio, bad debt reserves to receivables, operating cash flow to total assets, and Cash Coverage Ratio (CCR).

\section{The Cash Conversion Cycle (CCC)}

Cash analysis can be made using different methods, among these is CCC. In the current study, CCC had been used as a method for exercising cash analysis. CCC refers to the length of time inventory takes to be converted to cash. In other words, the conversion cycle is used as a metric to measure the number of days, a company needs to convert its resource inputs to cash. It encompasses, the number of days in average to pay accounts payable, average number of days the company needs to convert inventory to sales, and the number of days in average, a firm needs to collect its accounts receivables. CCC is computed using the following formula:

$$
C C C=D I O+D S O+D P O
$$

where:

DIO. Refers to average number of days inventory outstanding.

DSO. Refers to average number of days sales outstanding

DPO. Refers to average number of days payables outstanding.

There are several related theories of cash management, but only three common theories are considered in this situation. The most common three theories of cash include, pecking order theory, trade-off theory, and free cash flow theory. Myers (1984), and Myers and Majlaf (1984), founded the ground of pecking order theory. An order of financing is preferred to be followed whenever firms need funds, according to Myer (1984). Internal resources of funds comes first, then adjusting the dividends level, followed by selling the liquid assets, then using external resources, and the issuance of equity is given the last order. Based on theory, cash holding is a result of two decisions, investment decision, and financing decision, where a firm uses its cash flows to finance its investment opportunities and pays the debt when due, and the excess amounts of cash is kept accumulated over time. In times where cash flows are not enough to cover the debt or expenditures payment, the firm uses its prior accumulated amounts of cash, which is called reserves, but when operating cash flows is inadequate, additional financing is used. Trade-off theory is actually based on weighing the marginal benefits of holding cash against the marginal cost of cash holding, where the objective is to maximize the owners' wealth. A side of the trade-off theory is related in its roots to Keynes (1936), especially with regard to the motives of holding cash (Tahir et al. 2016). Three motives or benefits are available of cash availability including, transaction cost motive, precautionary motive, and speculation motive. In line with transaction cost benefit, holding cash enables firms to avoid the cost of fund raising or liquidating assets for the payment for the firm transactions. With regard to precautionary motive, cash holding enables firms to pay for their investment opportunities when other financing alternatives are unavailable (Aljawarneh \& Atan, 2018). Speculative motive means that holding cash and other short-term marketable securities enable firms to achieve benefits when interest rate of funding is raised. These benefits of holding cash and marketable securities are compared with the cost of holding cash and securities because short-term securities generate low rates of return.

The theory of free cash flows considers corporate managers as agents of shareholders, and shareholders are the principal, and agents should serve the interests of the principal, where a conflict of interests may occur between principals and agents because agents may have different goals and interests than the goals and interests of principals, so agents may act to achieve their goals at the expense of principals' goals. Agents try to hold high amounts of cash to achieve more control on assets, whereas investors prefer holding low levels of cash (Jensen, 1986). Regarding the prior related research, several prior studies had been done regarding cash management and financial performance relationship. The issue of cash management and its relation with financial performance deserves more attention by academic, practitioners, and other interested people. Bari et al. (2019), carried out a study to investigate cash management practices of food and beverage retailers of Puntland in Somalia, and determine the impact of cash management on profitability and sustainability. The authors' knowledge of three theories had been applied in the study including; (1) accrual theory of accounting, (2) trade credit theory, and (3) agency theory. A descriptive survey had been followed in the study to achieve its objectives based on a sample consisting of 39 food and beverage retailers. Using the correlation and regression methods in data analysis and hypotheses testing the study showed that food and beverage retailers of Puntland have low liquidity ratio because of fluctuations in food and beverages market, and cash flow of these retailers is not consistent (Alshare et al., 2020). Nso (2018), investigated the techniques that can be used in managing cash, and examined the relationship between cash management and firm profitability of microfinance institutions of Cameroon. The case study design 
was adopted by the author, and the study is an integration between quantitative and qualitative, and the data is both primary and secondary. Interviews with a sample consisting of 30 employees had been followed, in addition to quantitative methods that were used for the collected secondary data. The correlation method is used in the analysis and hypotheses testing. The study found that a significant positive relationship exists between cash management and the profitability of microfinance institutions of Cameroon. Kakeeto et al. (2017), carried out a case study to explore how cash management affects profitability Gumutindo Coffee Cooperative Enterprise Limited in one District of Uganda. Following probability and non-probability sampling techniques, a sample consisting of 181 employees had been drawn and responded to the study questionnaire. Using the Pearson correlation method, the study revealed that cash management has a significant positive effect on the profitability of Gumutindo Cofee. The data analysis also showed that $16.4 \%$ of the change in coffee profitability is explained by cash management.

Duncan et al. (2015), investigated the effect of cash management on the financial performance of deposit taking SACOOs in Mount Kenya Region. A self-administered structured questionnaire was used as the main resource of data collection. The data received from a simple random based sample consisting of 92 respondents, had been used in the analysis and hypothesis testing to determine whether cash management affects firm financial performance. Using descriptive and inferential statistics, the study showed that there is a need to introduce cash management controls in SACOOs, and strengthen SASRA and increase its awareness, in addition to the need to introduce credit management policy and increasing governmental monitoring. Ndirango (2014), carried out a study to examine whether cash management has an effect on the financial performance of the listed firms at Nairobi Stock Exchange. Descriptive research design had been employed in the study based on a sample consisting of 15 listed firms at Nairobi Securities Exchange. The data of the period 2010-2016 of the included firms in the sample had been collected and used in the analysis and hypotheses testing. Using the multiple regression method and correlations, the study found that CCC and size have no significant effect on financial performance, while leverage has a positive significant effect. One more study carried out by John (2014), investigated the effect of cash management on profitability of the Nigerian Manufacturing firms. The study mentioned that cash management is important to be efficient for the success of business. CCC is used as an indicator for cash management, while return on equity and return on assets were used as measures of firm profitability. A sample of 15 manufacturing Nigerian firms were selected, and data covering the period 2008-2012 is used in the analysis and hypotheses testing. Using correlation and regression, the study showed a significant positive relationship between cash management and return on equity, and insignificant negative relationship between cash management and return on assets. One important study carried out in Nigeria by Abioro (2013), regarding the effect of cash management on financial performance. Primary and secondary data had been used in the analysis. The structure of the study was based on financial performance as a dependent variable, and cash management as independent. Using the correlation method in hypothesis testing, the study showed an existence of significant relationship between cash management and financial performance of firms. Moreover, the study indicated that the existence of a high amount of cash in a firm does not insure good financial performance in case that no efficient management exists. Cash management was within the interests of Babil, (2012). The purpose of the study was to determine how a firm liquidity can be improved through cash management for Johnson's Byggnads AB. The data of the study is mixed of primary and secondary data, where this data had been collected through interviews and financial statements. The study demonstrated that the liquidity position of Johnson's Byggnads is good despite no body employed to manage liquidity. The study also showed that even though Jonsons Byggneds has a good liquidity position, still there are some areas that can be improved.

\section{Study Hypotheses}

Based on the consideration of the related literature and the prior researches, the hypotheses of the study had been developed, and listed, in their null form, as follows.

$\mathrm{H}_{01}$ : There is no significant effect of cash conversion cycle of listed chemical firms in Amman Stock Exchange on the return on equity of these firms.

$\mathrm{H}_{02}$ : There is no significant effect of cash conversion cycle on earnings per share of the listed chemical firms in Amman Stock Exchange.

\section{Research Methodology}

The population of the study includes the chemical listed firms at ASE. An included firm in the sample is required to satisfy two conditions. Conditions regarding the firms included in the sample had been set in advance, where a selected firm within the sample should be listed along the study period which extends along the period 2010-2019. Moreover, complete data covering the requirements of the study, of a selected firm within the sample, should be available on an annual basis. The web site of ASE is showing a total of 6 listed firms by the end of 2020. When the required data of each listed chemical firm had been considered, one among the 6 firms found having incomplete annual published information. Therefore, the firm of incomplete annual published information had been excluded, so the sample consists of the remaining 5 chemical firms. The dependent variable of the study is firm financial performance, or firm profitability since the term profitability is used as a reciprocal to financial 
performance, by different interested parties. Two measures of profitability were used, including the Return on Equity (ROE), and Earning Per Share (EPS), whereas CCC is used as the single independent variable. Current Ratio (CRO), and firm Size (FSZ), represented by the natural logarithms of total assets, are used as control variables. ROE is computed by dividing net income by shareholders' equity, and EPS can be found by deducting preferred shareholders' dividends, then dividing the remainder of net income by the average number of common shares outstanding. With regard to CCC, it identifies the number of days a firm takes to purchase inventory and converts this inventory to cash. CCC calculation is based on three financial ratios including, (1) days inventory outstanding, (2) days sales outstanding, and days payables outstanding. Thereafter, the CCC is computed as given in Eq. (1).

The linear regression method that is adopted to test the hypotheses of the study. Therefore, the regression model that accommodates the different types of variables, when ROE is used as a dependent variable, is as shown below.

$$
R O E=a+b C C C+c C R O+d F S Z+e
$$

where, $a$, is a constant representing the value of ROE, when the value of the corresponding variable equals zero, $b$ is the slope of CCC, which is briefly used to identify the change in ROE, as a result of the change in CCC. Regarding c, and d, each refers to the slope of CRO and FSZ, respectively. CCC refers to the cash conversion cycle, and CRO refers to the current ratio, whereas, FSZ is used to refer for the natural logarithms of total assets. Finally, e, represents the standard error. The linear regression method that is adopted to represent the structure of the study, and Eq. (3) to accommodate the different types of variables, when EPS is used as dependent variable, is as shown below.

$$
E P S=a+b C C C+c C R O+d F S Z+e
$$

Hypotheses are tested at 95 percent level of confidence, where this is equivalent to $0.05(1-0.95)$ level of significance, based on t-value, in addition to the value of significance. Descriptive statistics including the mean as a measure of central tendency, and the standard deviation as a measure of variation, were used in data analysis. Correlation is used to support the data analysis. The decision rule base is to accept the null hypothesis when the computed t-value is less than the corresponding tabulated one, which equals 1.96, and to reject it when the computed t-value is higher than the tabulated. Moreover, and as a reciprocal decision rule base, a comparison is done between the computed coefficient of significance and the predetermined one, which equals 0.05 , where a null hypothesis is accepted when the computed coefficient of significance is higher than the predetermined one, which equals 0.05 , and rejected when, in opposite, the computed coefficient of significance is less than the predetermined.

\section{Results and Analysis}

\subsection{Descriptive Statistics}

Descriptive statistics including the mean as the most important measure of central tendency and the standard deviation as preferred measure of variance were used in data analysis. Table 1 shows the mean and the standard deviation of each variable included in the study, whether the variable is dependent, independent, or control variable. The consideration of the table reveals that the mean of ROE is JD 0.368 , with 0.998 standard deviation, which is considered good, when compared by the low par value of common shares, which equals JD 1. With regard to EPS, the table shows a mean of JD 0.424, with JD 1.086 standard deviation, which is considered an indication of good financial performance. Based on information appearing in the table, the $\mathrm{CCC}$ is too long, where this indicates that in general, the cash conversion cycle is long, where this length of CCC refers to low efficiency in the management of receivables, inventory, or payables payment. The mean of current ratio equals 3.081 times, with 1.677 standard deviation, which seems within the range, when recognizing that the ideal value is 2 . The firm size is a control variable, and had been measured using the natural logarithms of total assets. The mean of total assets (using logarithms) equals $16.698 \mathrm{~m}$ with 0.35 standard deviation.

\section{Table 1}

Descriptive Statistics

\begin{tabular}{llll}
\hline Variable & Measure & No. of Cases & Mean \\
\hline Return on Equity & Jordan Dinar & 50 & 0.368 \\
Earnings Per Share & Jordanian Dinar & 50 & 0.998 \\
Cash Conversion Cycle & No. of Days & 50 & 1.086 \\
Current Ratio & Times & 50 & 407 \\
Firm Size & Assets Logarithms & 50 & 3.081 \\
\hline
\end{tabular}

\subsection{Correlation}

Table 2 shows the correlation coefficients among the variables. As appearing in the table, the correlation coefficient among $\mathrm{CCC}$, the single independent variable, and the dependent variables, equals 0.326 , with ROE, and 0.36 with EPS. The highest correlation coefficient equals 0.996 , which is available between both dependent variables, ROE and EPS, where strong correlation among the dependent variables doesn't reduce the reliability, nor the credibility of the study. The table shows -0.123 
coefficient of correlation between the independent variable CCC, and FSZ, represented by natural logarithms (log. Assets), and 0.217 between the independent variable CCC, and CRO. The coefficient of correlation between the two control variables, CRO and FSZ, is weak and negative, when it equals - 0.070. Actually, Table 2, involves information regarding correlation coefficients, where these coefficients support both of study reliability and credibility.

Table 2

Coefficients of Correlation

\begin{tabular}{llllll}
\hline & CCC & CRO & EPS & ROE & LOGAssets \\
\hline CCC & 1 & 0.217 & 0.326 & 0.360 & -0.123 \\
CRO & & 1 & 0.377 & 0.350 & -.070 \\
EPS & & 1 & 0.996 & 0.213 \\
ROE & & & 1 & 0.21 \\
FSZ & & & & 1 \\
\hline
\end{tabular}

\subsection{Hypotheses Testing}

The first hypothesis had been developed to enable testing whether cash management has a significant effect on the financial performance, through using ROE as a measure of financial performance. The first hypothesis is listed again, in its null form, as follows.

$\mathrm{H}_{01}$ : There is no significant effect of cash conversion cycle of listed chemical firms at Amman Stock Exchange on the return on equity of these firms.

The outputs received through SPSS, shows a coefficient of correlation (R) of 0.360 , and a coefficient of determination $\left(\mathrm{R}^{2}\right)$ of 0.130 . When control variables including CRO and FSZ were included in the test, the coefficient of correlation is 0.565 , while the coefficient of determination is 0.286 . Table 3 , shows the statistics related to the first hypothesis. The table shows that the computed t-value equals 2.672, and the coefficient of significance equals 0.010 . When the computed t-value is compared with its corresponding tabulated one, which equals 1.96, the comparison reveals that the computed one is higher than the tabulated. Moreover, when the computed coefficient of significance is compared with the corresponding predetermined one, the comparisons showed that the computed coefficient is less than the predetermined. Based on the results of comparisons, and because the computed t-value is higher than the tabular, and the computed coefficient of significance is less than the predetermined one, the null hypothesis is rejected, while instead, its alternative one is accepted. This means that the cash conversion cycle has a significant impact on return on equity. In other words, using ROE as an indicator for financial performance of the listed chemical firms at ASE, the results showed that the cash conversion cycle, as a measure of cash management, affects the financial performance of chemical firms of Jordan.

Table 3

The Related Coefficients to ROE

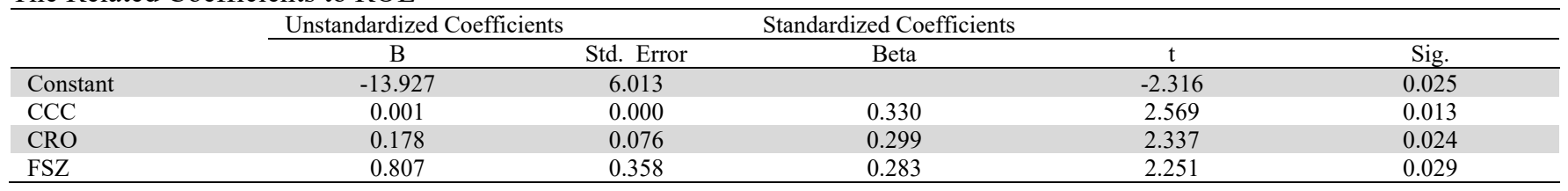

Based on the outputs of SPSS, which already included in table 3, the regression model resolved to be as follows.

$$
R O E=-13.927+0.001 C C C+0.178 C R O+0.807 F S Z+e
$$

The second hypothesis had been developed to enable testing the effect of CCC on the financial performance of listed chemical firms at ASE, using EPS as a dependent variable and representing financial performance, instead of ROE. EPS is a good measure of a firm's profitability, and can be used when all included firms in the sample are public holding firms. The hypothesis is listed, in its null form, again, as follows.

$\mathrm{H}_{02}$ : There is no significant effect of cash conversion cycle on earnings per share of the listed manufacturing firms at Amman Stock Exchange.

The outputs of SPSS showed a correlation coefficient (R) of 0.527 , and a coefficient of determination $\left(\mathrm{R}^{2}\right)$ of 0.278 , when control variables were included in the test. The outputs also showed that the adjusted $\mathrm{R}^{2}$ equals 0.23 . It is notable that no large difference exists between $R^{2}$, and the adjusted $R^{2}$. With regard to the difference between $R^{2}$ and the adjusted $R^{2}$, it is known that as the number of observations is small, and the number of independent variables (predictors) is large, the difference between 
the value of $\mathrm{R}^{2}$ and the adjusted $\mathrm{R}^{2}$ will be large enough, while in contrast, when the number of predictors is low, and the number of observations is high, the difference between $\mathrm{R}^{2}$ and the adjusted $\mathrm{R}^{2}$ will be low. On occasion, the adjusted $\mathrm{R}^{2}$ yields a more honest value to estimate the $\mathrm{R}^{2}$ for the population.

\section{Table 4}

The Related Coefficients to EPS

\begin{tabular}{|c|c|c|c|c|c|}
\hline & \multicolumn{2}{|c|}{ Unstandardized Coefficients } & \multirow{2}{*}{$\frac{\text { Standardized Coefficients }}{\text { Beta }}$} & \multirow[b]{2}{*}{ t-Value } & \multirow[b]{2}{*}{ Sig. } \\
\hline & $\mathrm{B}$ & Std. Error & & & \\
\hline Constant & -14.578 & 6.581 & & -2.215 & 0.032 \\
\hline $\mathrm{CCC}$ & 0.001 & 0.000 & 0.287 & 2.226 & 0.031 \\
\hline CRO & 0.216 & 0.083 & 0.334 & 2.598 & 0.013 \\
\hline FSZ & 0.843 & 0.392 & 0.272 & 2.148 & 0.037 \\
\hline
\end{tabular}

The most important related outputs of SPSS to the second hypotheses are available in table 4 . The table shows that the computed $\mathrm{t}$-value regarding the assumed effect of CCC on EPS, equals 2.226, and the computed coefficient of significance equals 0.031 . Comparing the computed t-value with its corresponding tabulated one, which equals 1.96, the comparison shows that the computed one is higher than the tabular. In addition, comparing the computed coefficient of significance with its corresponding predetermined one, which equals 0.05, the comparison shows that the computed is less. Because the computed t-value is higher than its corresponding tabulated one, and because the computed coefficient of significance is less than the corresponding predetermined one, the null hypothesis is rejected, and instead, its alternative is accepted. This result means that CCC has a significant impact on EPS, and thereafter, on financial performance of the listed chemical firms at ASE. Based on the outputs of SPS, and information available in table 4, the regression model of SPSS became as follows.

$$
E P S=-14.578+0.001 C C C+0.216 C R O+0.843 F S Z+e
$$

\section{Conclusions and Findings}

The main purpose of the study is to investigate whether the CCC has a significant impact on the financial performance of listed chemical firms at ASE. The effect of CCC on financial performance had been used using ROE, and EPS in a separate form, so two multiple regression models were used to test the hypotheses, one included ROE, while the other included EPS. Based on data analysis and hypothesis testing, the study showed that CCC affects the financial performance of chemical listed firms at ASE, when ROE is used as an indicator for financial performance. Also, the hypotheses testing showed that the financial performance of listed chemical firms at ASE is affected by the CCC, when EPS used as an indicator for financial performance, instead of ROE.

In both used models of regression in the study, two control variables were used, including CRO and FSZ, to achieve more credibility. The data analysis and hypotheses testing showed that each control variable has a significant impact on the financial performance.

\section{References}

Abioro, M. (2013). The impact of cash management on the performance of manufacturing companies in Nigeria. Uncertain Supply chain management, 1(3), 177-192.

Aljawarneh, N. M. S., \& Atan, T. (2018). Linking Tolerance to Workplace Incivility, Service Innovative, Knowledge Hiding, and Job Search Behavior: The Mediating Role of Employee Cynicism. Negotiation and Conflict Management Research, 11(4), 298-320.

Aljawarneh, N. M., Abd kader Alomari, K., Alomari, Z. S., \& Taha, O. (2020). Cyber incivility and knowledge hoarding: Does interactional justice matter?. VINE Journal of Information and Knowledge Management Systems.

Al-Omari, Z., Alomari, K., \& Aljawarneh, N. (2020). The role of empowerment in improving internal process, customer satisfaction, learning and growth. Management Science Letters, 10(4), 841-848.

Alsafadi, Y., Aljawarneh, N., Çağlar, D., Bayram, P., \& Zoubi, K. (2020). The mediating impact of entrepreneurs among administrative entrepreneurship, imitative entrepreneurship and acquisitive entrepreneurship on creativity. Management Science Letters, 10(15), 3571-3576.

Alshare, F., Aljawarneh, N., Alomari, K., Alomari, Z., Albdareen, R., AAlwagfi, A., \& Alradaideh, A. (2020). Factors influencing cellular device purchase decisions in Jordan. Management Science Letters, 10(11), 2501-2506.

Babil, D. (2012). Cash Management: Improving the Liquidity for Jonsond Byggnads with Cash Management. Master Thesis, Jönköping University, Available on Line at: http://hj.diva-portal.org/smash/get/diva2:545527/FULLTEXT01.pdf.

Bari, M. A., Muturi, W., \& Samantar, M. S., (2019). Effect of Cash Management on Financial Performance of Food and Beverage Retailers in Puntland State of Somalia: A case of Garowe District. International Journal of Contemporary Applied Researches, 6(3), 130-153. 
1346

Coyle, B., (2000). Framework for Credit Risk Management. Global Professional Publishing, London.

Duncan, D.N.M., Njeru, A., Member, F., \& Tirimba, O. I. (2015). Effect of Cash Management on Financial Performance of Deposit Taking SACCOs in Mount Kenya Region. International Journal of Scientific and Research Publications, 5(2), 1-6.

Guay, W. R., \& Harford, J., (2000). The Cash-Flow Performance and Information Content of Dividend Increases Versus Repurchases. Journal of Financial Economics, 57(3), 385-415.

Hamad, A., Al-Momani, M, \& Al Mawali, H., (2019). Does Accounting Conservatism Mitigate the Operating Cash Flows Downside Risk?. The Journal of Social Science Research, 5(2), 472-483.

Jensen, M.C. (1986). Agency costs of free cash flow, corporate finance, and takeovers. The American Economic Review, 76(2), 323-329

John, A. O. (2014). Effect of Cash Management on Firm Profitability of Nigerian Manufacturing Firms. International Journal of Technology Marketing. 4(1), 129-140.

Kakeeto, F., Micheal, T., Pastor, K., \& Osunsan, O. K., (2017). Cash Management and Organizational Profitability in GumutindoCofee Cooperative Enterprise Limited (GCCE), Mbale District Uganda. Journal of Research and Business Management, 5(5), 33-40.

Myers, S.C. (1984). The capital structure Puzzle. Journal of Finance, 39(3), 575-592.

Myers, S.C., \& Majluf, N.S. (1984).Corporate financing and investment decisions when firms have information that investors do not have. Journal of Financial Economics, 13(2), 187-221.

Ndirangu, L. W. (2014). Effect of Cash Management on the Financial Performance of the Companies Listed at the Nairobi Securities Exchange. Master Thesis, University of Nairobi.

Nso, M. A. (2018). Cash Management Techniques and the Relationship between Cash Management and Profitability of Microfinance Institutions. International Journal of Economics, Commerce and Management, 6(5), 468-481.

Patel, U. (2010). Cash Management at Indian Oil Corporations Ltd. Masters at Business Administration, DR. DY Patil University.

Peavler, R., (2009). Cash Management is Important for your Small Business. bizfinance.about.com/od/cashmanagement/a/cash_mngt.on 6/02/2013

Sloaga, H. G. (2012). Basics of Cash Management for Financial Management and Reporting. Available at: http://ssrn.com/abstract=2200432.

Tahir, M. S., Alifiah, M. N., Arshad, M. U., \& Saleem, F. (2016). Financial theories with a focus on corporate cash holding behavior: A comprehensive review. International Journal of Economics and Financial Issues, 6(3S).

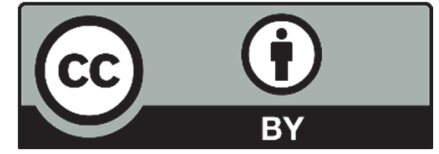

(C) 2021 by the authors; licensee Growing Science, Canada. This is an open access article distributed under the terms and conditions of the Creative Commons Attribution (CC-BY) license (http://creativecommons.org/licenses/by/4.0/). 